\title{
Posttraumatic growth among adolescents victims of bullying
}

\author{
Posttraumatic growth pada remaja penyintas bullying \\ Cokorde Istri Ayu Laksmi Dewi*1, Tience Debora Valentina ${ }^{1}$ \\ ${ }^{1}$ Universitas Udayana, Denpasar, Indonesia
}

\begin{abstract}
Being a victim of bullying is a traumatic life event that may lead to various developmental problems among adolescents. Such a traumatic life event could negatively affect individuals' emotional and physical well-being. However, for some individuals, traumatic life events could promote posttraumatic growth. The present paper describes posttraumatic growth among victims of bullying. Specifically, we describe some indicators and encouraging factors of posttraumatic growth among adolescents who had been victims of bullying. The present review can contribute to intervention programs to encourage posttraumatic growth among adolescents who had been victims of bullying.
\end{abstract}

Keywords: bullying, posttraumatic growth, adolescents

\begin{abstract}
Abstrak. Menjadi korban bullying merupakan peristiwa kehidupan traumatis yang dapat menimbulkan berbagai masalah perkembangan di kalangan remaja. Peristiwa kehidupan traumatis semacam ini dapat berdampak negatif pada kesejahteraan emosional dan fisik individu. Namun, bagi sebagian individu, peristiwa kehidupan traumatis dapat mendorong posttraumatic growth. Makalah ini menjelaskan posttraumatic growth di antara korban bullying. Secara spesifik, kami menjabarkan beberapa indikator dan faktor pendorong posttraumatic growth di kalangan remaja yang pernah menjadi korban bullying. Ulasan ini dapat berkontribusi pada program intervensi untuk mendorong posttraumatic growth di antara remaja korban bullying.
\end{abstract}

Kata Kunci: bullying, posttraumatic growth, remaja

\section{Pendahuluan}

Masa remaja sering dikatakan sebagai masa-masa paling indah dan tidak terlupakan. Pada masa remaja individu mulai mengenal dunia yang lebih besar di luar lingkungan keluarga, mulai menjalin banyak relasi pertemanan, dan mengalami indahnya kisah-kasih percintaan. Masa remaja merupakan masa perkembangan individu yang menghubungkan antara masa kanak-kanak dengan dewasa, atau dapat dikatakan sebagai masa peralihan dari anak-anak menuju dewasa. Ditinjau dari kategori usia, masa remaja berlangsung dalam kisaran 10-21 tahun (Santrock, 2011).

Ketika memasuki masa remaja, individu mengalami banyak perubahan baik fisik, kognitif, maupun sosio-emosional (Santrock, 2011). Menurut Erikson (n.d.) tugas perkembangan utama remaja yaitu menghadapi krisis atau kekacauan peran yang biasa disebut dengan pencarian jati diri untuk menemukan siapa dirinya, bagaimana sebenarnya dirinya, dan apa tujuan hidupnya. Oleh sebab itu, pertanyaan tentang "siapa saya?", "mengapa saya terlahir ke dunia ini?” sering terdengar dari

\footnotetext{
*Korespondensi: Cokorde Istri Ayu Laksmi Dewi, Fakultas Kedokteran, Universitas Udayana, Jl. P. B. Sudirman, Denpasar, Indonesia

Surel: laksmidewi28.ce@gmail.com
} 
remaja. Jika remaja mengeksplorasi peran-peran yang ada di masyarakat secara sehat dan sampai pada jalur positif, maka remaja dapat menemukan identitasnya; jika tidak, maka remaja akan mengalami kebingungan identitas atau yang disebut Erikson sebagai krisis identitas (Erikson, n.d.). Hal tersebut menunjukkan bahwa kebutuhan terpenting pada masa remaja yaitu "kebutuhan akan identitas", yang merupakan suatu kebutuhan untuk memahami diri dan menunjukkan diri kepada orang lain (Elkind, 1976). Berbagai perubahan, dan krisis pada masa remaja, serta keinginan remaja untuk menunjukkan jati diri menjadi tantangan yang membuat remaja rentan menghadapi berbagai permasalahan. Salah satu permasalahan relasional yang cukup krusial yaitu bullying di kalangan remaja.

Bullying didefinisikan sebagai tindakan penyalahgunaan kekuatan fisik maupun mental yang dilakukan seorang individu atau sekelompok individu kepada individu lain yang lebih lemah dan tidak mampu membela diri (Yayasan Semai Jiwa Amini, 2008). Ketika individu masih anak-anak hal terpenting adalah keluarga, namun ketika masa remaja hal terpenting adalah teman dan bagaimana remaja dapat bergabung dengan kelompok-kelompok pertemanan tertentu (Santrock, 2011). Oleh karena itulah remaja cenderung untuk melakukan konformitas agar dapat diterima oleh lingkungan pertemanannya. Konformitas terhadap kelompok teman sebaya tidak selalu memberikan dampak positif dalam relasi pertemanan remaja. Penelitian menemukan bahwa konformitas yang dilakukan remaja secara signifikan berhubungan positif dengan bullying, yaitu semakin tinggi konformitas remaja terhadap teman sebayanya, maka semakin tinggi pula kecenderungan remaja untuk melakukan bullying (Febriyani dan Indrawati, 2016; Shafiira, Widiastuti, dan Pratama, 2020).

Bullying kerap kali terjadi di beberapa lingkungan seperti keluarga, sekolah, kelompok pertemanan, lingkungan tempat tinggal, dan media sosial. Salah satu kasus bullying yang sempat menjadi pemberitaan yang cukup menggegerkan di Indonesia yaitu seorang remaja laki-laki berusia 12 tahun, yang merupakan penjual jalangkote di-bully oleh 8 orang pemuda dengan cara di takut-takuti, dipukul, dan didorong hingga dirinya, sepeda, dan semua dagangannya jatuh ke aspal (Mandegani, 2020). Bullying yang dialami remaja tersebut tidak diketahui alasan atau penyebabnya pastinya. Kondisi demikian juga sering terjadi pada remaja yang mengalami bullying, remaja tidak memahami mengapa orang di sekitarnya melakukan bullying terhadap mereka. Melihat kasus bullying yang cukup sering terjadi di kalangan remaja, bullying tentunya menjadi pengalaman buruk bagi remaja yang pernah menghadapinya. Hidup sebagai individu yang menjadi sasaran bullying tidaklah mudah, sebagian individu menganggap bahwa bullying merupakan suatu beban hidup atau hantaman besar yang menimbulkan luka yang sangat dalam dan sulit untuk disembuhkan. Layaknya asteroid yang menghantam bumi dan menyisakan kawah luas dan dalam.

Jumlah kasus bullying yang terjadi di dunia terbilang tinggi. Berdasarkan data yang dihimpun oleh Unesco, diperkirakan sekitar 246 juta anak dan remaja di dunia mengalami berbagai bentuk kekerasan dan bullying di sekolah setiap tahunnya (UNESCO, 2017). Sementara di Indonesia, berdasarkan data publikasi yang dihimpun dari bank data Komisi Perlindungan Anak Indonesia (KPAI), jumlah kasus bullying pada anak dan remaja periode tahun 2011-2016 mencapai 1.174 kasus (Komisi Perlindungan Anak Indonesia, 2016). Data terbaru berupa akumulasi dari tahun 2011-2019 yang tercatat oleh KPAI, telah terjadi kasus bullying sebanyak 2.473 kasus dengan tren yang terus meningkat (Komisi Perlindungan Anak Indonesia, 2020).

Beberapa bentuk bullying yang sering terjadi yaitu: bullying fisik berupa kontak fisik antara pelaku dan penyintas bullying, bullying verbal berupa ucapan atau kata-kata yang ditujukan kepada 
penyintas bullying, dan bullying psikologis berupa tindakan tersirat yang menyerang psikologis penyintas bullying (Yayasan Semai Jiwa Amini, 2008). Senada dengan pendapat tersebut, bentuk bullying yang sering terjadi di kalangan remaja meliputi: bullying verbal seperti ucapan yang tidak pantas, pemberian julukan, jelek, celaan, dan ancaman secara verbal; bullying fisik seperti memukul, mencekik, menendang, meludahi, merusak dan menghancurkan barang; serta bullying psikologis seperti pengucilan secara relasional, lirikan mata, helaan nafas, tawa mengejek serta bahasa tubuh yang kasar (Aini, 2016; Umamy, Hidayat, dan Sitorus, 2019).

Berbagai bentuk bullying yang dialami remaja memberikan dampak negatif yang signifikan pada beberapa aspek diri remaja seperti aspek kognitif dan akademis, emosional, serta relasi sosial. Adapun dampak bullying pada aspek kognitif dan akademis berupa terhambatnya proses belajar dan prestasi akademik. Hal tersebut dibuktikan oleh penelitian Harahap dan Saputri (2019) tentang dampak psikologis pada siswa yang menjadi penyintas bullying yang menemukan bahwa anak atau remaja penyintas bullying menjadi pasif dan kurang fokus dalam belajar serta tidak mengalami perkembangan dalam prestasi akademiknya. Smokowski, Evans, dan Cotter (2014) menemukan bahwa remaja penyintas bullying memiliki kepuasan sekolah yang rendah, persepsi yang kuat akan adanya diskriminasi, dan dampak buruk dalam proses pembelajaran remaja di sekolah pada tahun-tahun berikutnya. Penelitian yang dilakukan oleh Delprato, Akyeampong, dan Dunne (2017) yang menguji dampak bullying terhadap hasil belajar siswa kelas enam di 15 negara Amerika Latin menunjukkan adanya kesenjangan antara siswa yang mengalami bullying dan tidak mengalami bullying pada kemungkinan untuk meraih prestasi belajar, karena bullying merusak proses pembelajaran siswa. Temuan dari ketiga penelitian diatas menunjukkan bahwa bullying memberikan dampak negatif yang sangat signifikan pada perkembangan kognitif dan kehidupan akademis anak dan remaja.

Dampak negatif secara emosional juga dialami oleh remaja penyintas bullying. Slonje, Smith, dan Frisén (2016) menemukan bahwa remaja penyintas bullying akan mengalami pengalaman emosi negatif seperti selalu merasa ketakutan atau terancam untuk berada di lingkungannya. Bullying juga dapat menyebabkan remaja mengalami depresi. Hal tersebut dibuktikan oleh penelitian Ramadhani dan Retnowati (2013) yang menemukan adanya hubungan positif antara bullying dengan depresi. Hal serupa juga ditemukan oleh penelitian Mishra, Thapa, Marahatta, dan Mahotra (2018) bahwa remaja yang mengalami bullying cenderung mengalami tingkat depresi yang tinggi. Tingginya tingkat depresi yang dialami penyintas bullying dapat mengarah pada pikiran dan tendensi untuk melakukan bunuh diri di kemudian hari (Takizawa, Maughan, dan Arseneault, 2014). Penelitian lain menemukan pada remaja yang mengalami bullying, akan menarik diri dari lingkungannya (Ardiavianti, Kurnia, dan Hsieh, 2018). Kecenderungan penyintas bullying menarik diri dari lingkungan pertemanannya juga ditemukan oleh Hardi, Kharis, dan Aini (2019) pada penelitiannya mengenai dampak bullying pada siswa SMKN 5 Mataram.

Beberapa hasil penelitian di atas menunjukkan fakta bahwa bullying dapat menghasilkan dampak negatif pada individu yang mengalaminya. Akan tetapi, mengalami bullying juga dapat dimaknai berbeda oleh remaja sehingga menghasilkan dampak berbeda pada individu-individu yang berbeda. Bagi beberapa individu, pengalaman menghadapi bullying dapat berubah menjadi suatu pengalaman hidup berharga yang memicu dirinya untuk berjuang sehingga mencapai perubahan psikologis yang positif, seperti menjadi pribadi yang lebih baik, lebih kuat, lebih sukses, dan lebih bahagia. Individu yang demikian disebut sebagai individu yang mengalami posttraumatic growth (Calhoun dan Tedeschi, 
2014).

Menurut Calhoun dan Tedeschi (2004) proses tercapainya posttraumatic growth pada individu diawali ketika individu mengalami kejadian yang menimbulkan stres yang berat, terlihat pada awalnya individu mungkin merasa sangat tertekan, namun perasaan tertekan tersebut menimbulkan evaluasi dan tantangan terhadap core believe atau keyakinan individu tentang dunia beserta posisi individu tersebut di dunia. Tantangan terhadap keyakinan individual tersebut memunculkan pemrosesan kognitif berupa perenungan yang mendalam dengan terus memikirkan kejadian yang dialami serta mencari cara untuk keluar dari masalah tersebut. Proses inilah yang membawa individu sampai pada kondisi posttraumatic growth, yang dalam prosesnya dipengaruhi oleh faktor internal dan eksternal individu.

Mengetahui bahwa individu yang mengalami kejadian penuh stres dapat menghasilkan pertumbuhan yang positif atau posttraumatic growth, tentunya sangat menarik untuk mengkaji mengenai hal tersebut pada remaja penyintas bullying. Disamping itu, literatur yang membahas posttraumatic growth pada penyintas bullying juga masih sangat terbatas (Tennen, 2013). Oleh sebab itu, tulisan ini bertujuan untuk mengkaji dan menggali lebih dalam tentang remaja penyintas bullying yang mengalami posttraumatic growth, indikator posttraumatic growth, serta faktor yang berperan dalam pembentukan posttraumatic growth pada remaja penyintas bullying.

\section{Pengertian posttraumatic growth}

Posttraumatic growth adalah suatu perubahan psikologis positif sebagai hasil perjuangan individu terhadap suatu kejadian yang sangat menantang, menekan, dan traumatis (Calhoun dan Tedeschi, 2014). Posttraumatic growth bukan merupakan akibat langsung dari trauma melainkan hasil perjuangan individu dengan realitas baru setelah trauma. Kondisi tersebut disebabkan keadaan yang menantang, menekan, dan traumatis, atau disebut sebagai tantangan yang signifikan terhadap sumber daya adaptif individu, terhadap cara individu memahami dunia, dan posisi individu di dunia, sehingga dapat mengarahkan individu menuju posttraumatic growth (Tedeschi dan Calhoun, 2004). Pada sebagian besar individu, bukanlah hal yang mudah untuk mencapai posttraumatic growth, karena posttraumatic growth dicapai melalui perjuangan individu yang tiada henti dengan usaha dan niatan yang kuat untuk menghasilkan pemaknaan dan respon psikologis yang positif atas suatu pengalaman buruk yang dialami (Tedeschi dan Calhoun, 1999).

Tedeschi dan Calhoun (1999) mengungkapkan individu mencapai posttraumatic growth melalui beberapa tahap, diawali dengan munculnya peristiwa traumatis dalam hidup individu yang dapat menyebabkan guncangan besar atas pemahamannya terhadap dunia, bagaimana dunia bekerja, dan seperti apa posisinya di dunia, yang mana hal tersebut memunculkan aktivitas kognitif yang mengganggu dan otomatis, serta emosi negatif, sehingga individu akan melakukan rumination atau perenungan dan mencurahkan banyak energi untuk memikirkan kejadian tersebut; selanjutnya, rumination melibatkan berbagai proses kognitif, pemikiran berulang, hati-hati, dan kadang menimbulkan perasaan yang tidak nyaman ketika terus memikirkan kejadian tersebut, sehingga individu cenderung berusaha menemukan cara untuk keluar dari masalah atau mengembalikan keseimbangan emosional dan kognitifnya; proses rumination yang sebelumnya terjadi dapat meningkatkan kemungkinan bagi individu untuk dapat terlepas dari masalah melalui proses adaptif atau perjuangan; Proses adaptif dari rumination memungkinkan peningkatan kemampuan coping untuk mengurangi tingkat tekanan emosional; ketika 
individu berhasi melakukan coping yang efektif dan mengarah pada penerimaan serta pertumbuhan pribadi ke arah yang lebih positif, maka individu tersebut dapat mencapai posttraumatic growth.

Penelitian menemukan, individu yang mengalami pengalaman traumatis melaporkan adanya tingkat perubahan diri positif yang lebih tinggi, karena pengalaman traumatis yang dialami mendorong pemrosesan kognitif yang mengarahkan individu pada posttraumatic growth (Taku, Kilmer, Cann, Tedeschi, dan Calhoun, 2012). Namun demikian, individu yang mengalami kejadian traumatis dan menerima kondisinya yang dapat termotivasi untuk mencari makna dan arah baru dalam hidupnya, sehingga dapat memfasilitasi pertumbuhan yang positif (Kleim dan Ehlers, 2009). Kemampuan individu untuk menerima keadaan yang tidak dapat diubah merupakan hal yang sangat penting untuk beradaptasi dengan peristiwa traumatis, kondisi ini merupakan salah satu prediktor posttraumatic growth (Haas, 2015). Implikasi pemaparan tersebut memberikan gambaran bahwa individu yang mencari makna dan arah baru dalam hidupnya akan mengalami perubahan diri yang positif.

\section{Indikator posttraumatic growth pada remaja penyintas bullying}

Seorang remaja penyintas bullying dikatakan mencapai kondisi posttraumatic growth ketika remaja tersebut mengalami beberapa indikator dari posttraumatic growth. Menurut Calhoun dan Tedeschi (2014) terdapat lima indikator posttraumatic growth. Pertama, appreciation of life yang merujuk pada perubahan mengenai prioritas hidup individu seiring dengan peningkatan penghargaan terhadap hal yang masih dimilikinya, dan juga cara individu menghargai hal-hal yang awalnya dianggap kecil atau buruk, menjadi sesuatu yang penting dan penuh makna. Kedua, yaitu relating to others yaitu perubahan dalam relasi dengan orang lain, dengan memulai mengembangkan hubungan yang lebih dekat dengan orang lain, menjaga hubungan agar tetap baik, menjalin hubungan yang lebih intim, dan lebih berarti, serta berkembangnya perasaan altruisme dalam diri individu. Ketiga,personal strength yang merupakan kemampuan remaja untuk dapat mengenali dan mengembangkan kekuatan dalam dirinya, serta peningkatan atas kemampuan dan kekuatan tersebut. Keempat, new possibilities yang merupakan kemampuan remaja mengidentifikasi kesempatan atau peluang baru atau mengembangkan minat-minat, dan cita-cita yang ingin dicapai dalam hidupnya. Kelima, spiritual development yaitu peningkatan spiritualitas, yang ditandai dengan pendekatan diri kepada Tuhan, ataupun munculnya pertanyaan-pertanyaan eksistensial.

Kelima indikator posttraumatic growth yang dikemukakan oleh Calhoun dan Tedeschi (2014), dapat ditemukan pada remaja penyintas bullying. Penelitian Zakiyah, Fedryansyah, dan Gutama (2018) menemukan bahwa remaja yang mengalami bullying awalnya merasa sedih, menangis, malu, dan membolos sekolah selama dua minggu, bahkan berakibat penurunan nilai akademik di sekolah, akan tetapi dukungan sosial dari orangtua dan sahabat menolong remaja memaknai bullying sebagai kritik yang membangun untuk menjadi individu yang lebih baik lagi, bahkan bullying yang dialami berhasil mengubah penampilan remaja menjadi lebih menarik. Selain itu, penelitian tersebut juga menemukan bahwa remaja menggunakan strategi coping adaptif untuk mengatasi bullying. Penelitian ini juga menemukan bahwa adanya impian remaja penyintas bullying untuk melanjutkan sekolah ke jenjang yang lebih tinggi dan membuka bisnisnya sendiri. Hasil penelitian ini menunjukkan ada dua indikator posttraumatic growth yang dicapai oleh remaja penyintas bullying, yaitu appreciation of life berupa pemaknaan bullying sebagai kritik yang membangun untuk menjadi pribadi yang lebih baik, dan new possibilities berupa adanya keinginan untuk meraih cita-cita atau mengembangkan minat. 
Ellisyani (2016) mengungkapkan adanya indikator new possibilities pada remaja penyintas bullying, yaitu remaja penyintas bullying mulai mengembangkan tujuan hidup baru yaitu ingin meraih prestasi yang lebih baik demi membanggakan keluarga dan orang-orang terdekatnya. Penelitian ini juga menemukan adanya indikator appreciation of life, terwujud pada ungkapan remaja bahwa pengalaman bullying yang dialaminya merupakan suatu pengalaman berharga yang menjadi tantangan dan pelajaran hidup untuk dapat menjadi pribadi yang lebih percaya diri, lebih dewasa, dan sabar. Remaja juga mengungkapkan bahwa kehidupannya saat ini menjadi lebih bahagia karena dukungan sosial yang diterima dari keluarga, dan orang-orang sekitar sehingga berhasil menghadapi tantangan-tantangan yang muncul ketika mengalami bullying. Selain indikator new possibilities dan appreciation of life, penelitian juga menunjukkan bahwa remaja mampu menghadapi bullying dan mencapai indikator spiritual development yang dapat dilihat dari penanaman keyakinan dalam diri bahwa Allah tidak memandang kelebihan maupun kelemahan hamba-Nya.

Penelitian Khoirunnisa (2015) juga menunjukkan bahwa dukungan sosial dari orangtua membuat remaja penyintas bullying mampu membuktikan dirinya mampu menjadi orang yang lebih baik, bahkan dibandingkan dengan teman-teman yang melakukan bullying kepadanya, dengan cara menonjolkan kemampuan akademik yang dimilikinya. Selain itu, dukungan sosial juga membuat remaja mampu memperbaiki relasi dengan teman dan mengembangkan altruisme dalam dirinya dengan berupaya untuk ikhlas membantu teman-temannya yang membutuhkan bantuan. Penelitian ini juga menunjukkan bahwa remaja penyintas bullying berkeinginan untuk mengikuti kegiatan-kegiatan yang diminati dan disukainya. Berdasarkan hasil penelitian ini, dapat dilihat bahwa terdapat tiga indikator posttraumatic growth yang terbentuk pada remaja penyintas bullying, diantaranya personal strength, relating to others, dan new possibilities.

Beberapa indikator posttraumatic growth ditemukan pula pada penelitian Utomo (2016), yaitu remaja yang awalnya merasa tertekan, stres, dan merasa tidak adil atas bullying yang dialaminya, berubah menjadi tidak menarik diri dan berusaha untuk membangun hubungan yang lebih baik dengan teman-teman yang melakukan bullying karena peran dari dukungan sosial orangtua dan temannya, serta menggunakan strategi coping aktif. Hal tersebut menggambarkan munculnya indikator relating to others. Penelitian ini juga menunjukkan pencapaian dari indikator personal strength yaitu bullying membuat remaja mulai mengenali dan menilai kelebihannya sehingga remaja merasa mampu serta berani untuk menghadapi permasalahan apapun tanpa harus menghindari masalah tersebut. Selain kedua indikator tersebut, hasil penelitian ini juga menggambarkan indikator spiritual development yang dapat dilihat dari pendekatan diri remaja kepada Tuhan melalui berdoa, dan menyerahkan sepenuhnya masalah yang dihadapi kepada Tuhan.

Penelitian berikutnya yang menunjukkan adanya pencapaian indikator posttraumatic growth pada penyintas bullying yaitu penelitian yang dilakukan oleh Ratcliff, Lieberman, Miller, dan Pace (2017) yang bertujuan untuk melihat ekspresi atau ungkapan spontan terkait indikator posttraumatic growth pada anak dan remaja penyintas bullying yang mengalami gangguan penglihatan. Penelitian tersebut menunjukkan bahwa anak dan remaja penyintas bullyingberhasil menunjukkan tiga indikator posttraumatic growth. Ketiga indikator tersebut yaitu pertama personal strength, yang digambarkan oleh ungkapan bahwa bullying membuatnya lebih kuat, dan bullying memang awalnya menyakitkan, namun akhirnya membuatnya berjuang untuk melakukan yang lebih baik lagi. Kedua, yaitu new possibilities dapat dilihat pada ungkapan yang menyatakan bahwa bullying membantunya untuk terlibat 
dengan olahraga. Ketiga, yaitu appreciation of life yang berupa ungkapan bahwa bullying yang dialami membuatnya lebih menghargai hidup dan memeloreh pencapaian yang lebih besar dari sebelumnya, dimana mereka belajar untuk menyadari bahwa dirinya berharga dan membanggakan atas semua pencapaian atletik dan akademiknya.

Sari dan Jatiningsih (2015) juga menemukan bahwa remaja penyintas bullying dapat mencapai indikator personal strength. Hal tersebut dapat dilihat dari hasil wawancara dengan remaja penyintas bullying yang mengungkapkan bahwa awalnya bullying menimbulkan perasaan sedih, namun perasaan sedih akibat bullying membuat remaja mencoba untuk mengevaluasi kekurangan-kekurangan dalam dirinya kemudian mengubah kekurangan tersebut menjadi kelebihan sehingga dapat menjadi pribadi yang lebih baik. Kemudian dia juga menemukan remaja penyintas bullying yang berhasil mengenali kekurangannya serta berubah menjadi pribadi yang lebih baik, membuatnya lebih disukai oleh temantemannya, sehingga lebih nyaman berada di kelas.

Paparan sebelumnya menunjukkan bahwa terdapat lima indikator posttraumatic growth yang dapat dijadikan acuan untuk melihat apakah individu yang mengalami kejadian traumatis atau pengalaman buruk yang menimbulkan stres yang cukup berat di hidupnya berhasil mencapai posttraumatic growth (Tedeschi dan Calhoun, 2004). Berdasarkan kajian mengenai indikator posttraumatic growth ini juga diketahui bahwa remaja penyintas bullying dapat mencapai beberapa indikator dari posttraumatic growth, yang mana pada setiap remaja akan mencapai beberapa indikator yang berbeda-beda dengan kondisi yang berbeda-beda pula.

\section{Faktor-faktor yang membentuk posttraumatic growth pada remaja penyintas bullying}

Beragam literatur menjelaskan beberapa faktor yang membentuk individu untuk mengalami posttraumatic growth. Faktor pertama yaitu karakteristik personal. Salah satu karakteristik personal yang dapat mengarahkan remaja penyintas bullying pada pencapaian posttraumatic growth yaitu self-reliance. Self-reliance adalah keyakinan individu untuk mampu secara mandiri mengatasi stres dan masalah yang dihadapinya (Reynolds dan Kamphaus, 2004). Penelitian membuktikan, remaja yang memiliki self-reliance yang kuat cenderung mengatasi bullying dengan cara menenangkan dirinya, menghadapi masalah dengan cara problem focused coping (berusaha mengambil tindakan penyelesaian), dan mencari dukungan yang dapat menghilangkan efek negatif dari bullying (Parris, Varjas, Meyers, Henrich, dan Brack, 2017). Analisis dari kerangka big five personality menemukan: karakteristik keterbukaan terhadap pengalaman (openness to experience) berkaitan dengan tiga dari lima domain posttraumatic growth yang meliputi kesempatan-kesempatan baru, relasi dengan orang lain, dan kekuatan individual; karakteristik conscientiousness merupakan faktor penting untuk memunculkan perubahan pada domain spiritual, kekuatan personal, dan apresiasi terhadap kehidupan yang mengarahkan individu pada penanganan peristiwa traumatis dan melakukan coping secara langsung terhadap suatu kejadian; karakteristik extraversion berhubungan dengan strategi coping individu, yaitu extraversion mendorong individu untuk melakukan pencarian dukungan, pemecahan masalah dan restrukturisasi kognitif; karakteristik agreeableness memungkinkan individu untuk mencari dukungan sosial untuk dapat menerima kejadian traumatis yang dialami; dan, karakteristik neuroticism juga merupakan faktor yang memengaruhi tercapai atau tidak posttraumatic growth, yaitu neuroticism cenderung menggunakan coping penghindaran (Karanci et al., 2012). Berdasarkan penjelasan tersebut, dapat dipahami bahwa 
beberapa perubahan pada aspek kepribadian sebagai hasil dari pengalaman buruk, mengarah pada perubahan sifat jangka panjang yang dapat memberikan wawasan penting untuk intervensi yang mendorong posttraumatic growth di masa depan (Zelenski, Santoro, dan Whelan, 2012).

Faktor kedua yaitu pengalaman traumatis. Pengalaman traumatis merupakan kejadian yang mengejutkan, menakutkan, dan berbahaya, yang dapat memengaruhi kondisi emosional maupun fisik individu, misalnya bencana alam, kekerasan, atau kecelakaan (National Institute of Mental Health, 2020). Seperti yang telah dijelaskan sebelumnya, bahwa posttraumatic growth merupakan hasil perjuangan terhadap kejadian traumatis, maka pengalaman traumatis dapat dikatakan sebagai salah satu faktor yang memengaruhi terbentuknya posttraumatic growth (Calhoun dan Tedeschi, 2014). Bullying merupakan salah satu tindakan yang dapat menimbulkan trauma dan stres bagi remaja penyintas bullying. Hal tersebut dibuktikan oleh penelitian Idsoe, Dyregrov, dan Idsoe (2012) bahwa remaja yang mengalami bullying menunjukkan adanya gejala posttraumatic stress disorder (PTSD), dan frekuensi paparan bullying yang semakin sering akan berdampak pula pada gejala PTSD yang lebih parah. Penelitian yang dilakukan oleh Andreou, Tsermentseli, Anastasiou, dan Kouklari (2020) yang meneliti tentang hubungan antara pengalaman bullying di sekolah dengan PTSD dan posttraumatic growth menemukan bahwa terdapat hubungan yang kurvilinier antara posttraumatic growth dengan tingkat keparahan gejala PTSD, yang mana fitur selektif seperti frekuensi dan durasi bullying yang sedang, akan memunculkan keparahan gejala PTSD yang sedang pula sehingga memunculkan posttraumatic growth yang tinggi, sementara frekuensi bullying yang lebih sering dan durasi yang lebih lama akan memunculkan keparahan gejala PTSD yang tinggi sehingga memunculkan posttraumatic growth yang sedang. Hubungan pengalaman traumatis dengan munculnya posttraumatic growth pada remaja korban bullying sejalan dengan proses atau tahap terjadinya posttraumatic growth yang dijelaskan oleh Tedeschi dan Calhoun (1999), yang salah satu tahapnya yaitu individu mengalami pengalaman traumatis terlebih dahulu sebelum berhasil mencapai posttraumatic growth.

Faktor ketiga yaitu strategi coping. Strategi coping yang digunakan oleh remaja ketika menghadapi bullying juga merupakan salah faktor penentu yang dapat mengarahkan remaja mencapai posttraumatic growth. Penelitian yang dilakukan oleh Evans, Cotter, dan Smokowski (2017) menemukan bahwa remaja penyintas bullying yang cenderung mencari bantuan kepada orangtua sebagai upaya untuk mendapatkan dukungan emosional dari orangtua (emotional focused coping) dan upaya untuk mendapat bantuan berupa tindakan untuk menghentikan bullying (problem focused coping). Salah satu penelitian juga menemukan bahwa strategi coping yang aktif dan adaptif mengarah pada kesehatan mental dan fungsi psikologis yang lebih baik, dalam hal ini remaja secara aktif mengubah situasi negatif menjadi situasi positif dengan cara mencari hubungan sosial dengan orang lain untuk menyelesaikan masalah (Ma dan Bellmore, 2016). Strategi coping kognitif atau regulasi emosi dapat meringankan tingkat depresi yang dialami remaja penyintas bullying, karena coping kognitif mendorong remaja untuk melakukan perenungan, positive refocusing, dan positive reappraisal (Garnefski dan Kraaij, 2014). Positive refocusing merupakan upaya untuk mengarahkan pikiran kepada hal-hal yang menyenangkan, sementara positive reappraisal yaitu pemaknaan positif terhadap suatu peristiwa sebagai bagian dari pertumbuhan personal (Garnefski, Kraaij, dan Spinhoven, 2001). Temuan penelitian membuktikan strategi coping yang melibatkan cognitive refocusing berhubungan dengan rendahnya pengalaman emosional negatif (Nixon et al., 2019), sehingga memungkinkan individu bergerak menuju perubahan yang lebih positif. 
Faktor ke-empat yaitu dukungan sosial. Dukungan sosial memainkan peran yang kuat dalam perkembangan posttraumatic growth, apabila diberikan secara stabil dan konsisten sepanjang waktu kepada individu yang membutuhkannya (Calhoun dan Tedeschi, 2014). Kelekatan dan dukungan orangtua pada remaja memainkan peran penting dalam menurunkan tingkat depresi dan memperbaiki dampak psikologis yang dialami remaja akibat bullying (Kim dan Yun, 2016). Persepsi terhadap dukungan sosial membuat remaja penyintas bullying merasa dipedulikan, merasa berharga, merasa menjadi bagian dari jaringan sosial, sehingga kondisi tersebut dapat meringankan dampak negatif bullying yang dirasakan remaja (Panayiotou dan Karekla, 2013). Penelitian Yin et al. (2017) juga menunjukkan bahwa dukungan sosial yang diperoleh dari teman dekat secara signifikan berhubungan negatif dengan tingkat depresi yang dialami remaja penyintas bullying, artinya semakin tinggi dukungan teman dekat maka semakin rendah tingkat depresi yang dialami. Tingginya tingkat dukungan sosial dari teman dan sahabat juga berkontribusi pada kemampuan remaja untuk mengatasi bullying yang dihadapi dan terus berupaya untuk melakukan hal yang disenangi atau diminatinya (Risner, 2014). Keinginan individu untuk mengembangkan minatnya merupakan salah satu indikator yang mengarah pada posttraumatic growth (Calhoun dan Tedeschi, 2014). Temuan penelitian yang dipaparkan tersebut menunjukkan dukungan orangtua dan teman sebaya menolong remaja untuk mengatasi bullying dengan berfokus pada pengembangan minat remaja.

Berdasarkan temuan dari beberapa penelitian diatas, dapat diketahui bahwa posttraumatic growth pada remaja penyintas bullying dipengaruhi oleh beberapa faktor, yaitu faktor kepribadian, dukungan sosial dari keluarga dan teman, strategi coping yang digunakan oleh remaja, dan juga pengalaman traumatis atau pengalaman bullying pada remaja.

\section{Kesimpulan}

Posttraumatic growth dapat terjadi ketika seorang individu mengalami peristiwa yang menekan lalu kemudian bangkit kembali. Pemaparan sebelumnya menunjukkan bahwa remaja yang mengalami bullying dapat mencapai posttraumatic growth, yang terlihat dari beberapa indikator posttraumatic growth. Remaja penyintas bullying yang mengalami posttraumatic growth dipengaruhi oleh beberapa faktor yaitu: faktor karakteristik personal dan strategi coping adaptif untuk mengatasi bullying, serta faktor dukungan sosial dari orangtua dan teman. Tulisan ini memberikan gambaran untuk mengembangkan kekuatan kepribadian remaja, strategi coping adaptif dan pelibatan dukungan sosial dari orang terdekat remaja seperti orangtua bagi program intervensi terhadap remaja penyintas bullying untuk membangun posttraumatic growth.

\section{Referensi}

Aini, S. Q. (2016). Fenomena kekerasan di sekolah (school bullying) pada remaja kabupaten pati. Jurnal Litbang, 12, 51-60.

Andreou, E., Tsermentseli, S., Anastasiou, O., dan Kouklari, E.-C. (2020). Retrospective accounts of bullying victimization at school: associations with post-traumatic stress disorder symptoms and post-traumatic growth among university students. Journal of Child dan Adolescent Trauma. https://doi.org/10.1007/s40653-020-00302-4

Ardiavianti, L., Kurnia, I. D., dan Hsieh, P. (2018). Relationship between bullying and social anxiety and withdrawal among adolescents. Proceedings of the 9th International Nursing Conference. 
Calhoun, L., dan Tedeschi, R. (2004). Posttraumatic growth in clinical practice (1st ed.). London: Routledge.

Calhoun, L., dan Tedeschi, R. (2014). Handbook of posttraumatic growth: Research and practice. New York: Taylor dan Francis.

Delprato, M., Akyeampong, K., dan Dunne, M. (2017). The impact of bullying on students' learning in Latin America: A matching approach for 15 countries. International Journal of Educational Development, 52, 37-57. https://doi.org/10.1016/j.ijedudev.2016.10.002

Elkind, D. (1976). Child development and education : A piagetian perspective. New York: Oxford University Press.

Ellisyani, N. (2016). Regulasi emosi pada korban bullying di SMA Muhammadiyah Palembang. Psikologi Islam, 2.

Erikson, E. (n.d.). Identity youth and crisis. New York: W. W. Norton dan Company, Inc.

Evans, C. B. R., Cotter, K. L., dan Smokowski, P. R. (2017). Giving victims of bullying a voice: A qualitative study of post bullying reactions and coping strategies. Child and Adolescent Social Work Journal, 34, 543-555. https://doi.org/10.1007/s10560-017-0492-6

Febriyani, Y. A., dan Indrawati, E. (2016). Konformitas teman sebaya dan perilaku bullying pada siswa kelas XI IPS. Empati, 5, 138-143.

Garnefski, N., dan Kraaij, V. (2014). Bully victimization and emotional problems in adolescents: Moderation by specific cognitive coping strategies? Journal of Adolescence, 37, 1153-1160. https://doi.org/10.1016/j.adolescence.2014.07.005

Garnefski, N., Kraaij, V., dan Spinhoven, P. (2001). Negative life events, cognitive emotion regulation and emotional problems. Personality and Individual Differences, 30, 1311-1327. https://doi.org/ 10.1016/S0191-8869(00)00113-6

Haas, M. (2015). Bouncing forward: Transforming bad breaks into breakthroughs.

Harahap, E., dan Saputri, N. M. I. (2019). Dampak psikologis siswa korban bullying di SMA Negeri 1 Barumun. Jurnal Bimbingan Dan Konseling, 4. https://doi.org/10.31604/ristekdik.v4i1.68-75

Hardi, M., Kharis, A., dan Aini, N. (2019). Dampak Bullying Terhadap Perilaku Remaja (Studi pada SMKN 5 Mataram). JIAP (Jurnal Ilmu Administrasi Publik), 7, 44. https://doi.org/10.31764/jiap. v7i1.775

Idsoe, T., Dyregrov, A., dan Idsoe, E. C. (2012). Bullying and PTSD symptoms. Journal of Abnormal Child Psychology, 40, 901-911. https://doi.org/10.1007/s10802-012-9620-0

Karanci, A. N., Işikli, S., Aker, A. T., Gül, E. I., Erkan, B. B., Özkol, H., dan Güzel, H. Y. (2012). Personality, posttraumatic stress and trauma type: Factors contributing to posttraumatic growth and its domains in a Turkish community sample. European Journal of Psychotraumatology, 3. https://doi.org/10.3402/ejpt.v3i0.17303

Khoirunnisa, R. (2015). Konsep diri remaja korban bullying (studi pada siswa korban bullying di SMA Muhammadiyah 7 Yogyakarta. Jurnal Riset Mahasiswa Bimbingan Dan Konseling. Retrieved from http://journal.student.uny.ac.id/ojs/index.php/fipbk/article/view/276

Kim, S., dan Yun, I. (2016). Bullying among South Korean adolescents: Prevalence and association with psychological adjustment. Violence and Victims, 31, 167-184. https://doi.org/https: //doi.org/10.1891/0886-6708.VV-D-13-00138

Kleim, B., dan Ehlers, A. (2009). Evidence for a curvilinear relationship between posttraumatic growth and posttrauma depression and PTSD in assault survivors. Journal of Traumatic Stress, 22, 
45-52. https://doi.org/10.1002/jts.20378

Komisi Perlindungan Anak Indonesia. (2016). Data kasus perlindungan anak berdasarkan lokasi pengaduan dan pemantauan media se-Indonesia tahun 2011-2016. Retrieved from https://bankda ta.kpai.go.id/tabulasi-data/data-kasus-se-indonesia/data-kasus-perlindungan-anak-berdasarkan -lokasi-pengaduan-dan-pemantauan-media-se-indonesia-tahun-2011-2016

Komisi Perlindungan Anak Indonesia. (2020). Sejumlah kasus bullying sudah warnai catatan masalah anak di awal 2020, begini kata komisioner KPAI. Retrieved from https://www.kpai.go.id/berita/se jumlah-kasus-bullying-sudah-warnai-catatan-masalah-anak-di-awal-2020-begini-kata-komisio ner-kpai

Ma, T.-L., dan Bellmore, A. (2016). Connection or independence: Cross-cultural comparisons of adolescents' coping with peer victimization using mixed methods. Journal of Cross-Cultural Psychology, 47, 109-130. https://doi.org/10.1177/0022022115605386

Mandegani, D. P. (2020). 6 fakta aksi perundungan anak penjual jalangkote yang viral di media sosial. Retrieved from https://www.merdeka.com/sumut/6-fakta-aksi-perundungan-anak-penjual-jalang kote-yang-viral-di-media-sosial.html

Mishra, D. K., Thapa, T. R., Marahatta, S. B., dan Mahotra, A. (2018). Bullying behavior and psychosocial health: A cross-sectional study among school students of Pyuthan municipality. Journal of Nepal Health Research Council, 16, 73-78. https://doi.org/10.33314/JNHRC.V16I1.1 366

National Institute of Mental Health. (2020). Coping with traumatic events.

Nixon, C. L., Jairam, D., Davis, S., Linkie, C. A., Chatters, S., dan Hodge, J. J. (2019). Effects of students grade level, gender, and form of bullying victimization on coping strategy effectiveness. International Journal of Bullying Prevention. https://doi.org/10.1007/s42380-019-00027-5

Panayiotou, G., dan Karekla, M. (2013). Perceived social support helps, but does not buffer the negative impact of anxiety disorders on quality of life and perceived stress. Social Psychiatry and Psychiatric Epidemiology, 48, 283-294. https://doi.org/10.1007/s00127-012-0533-6

Parris, L., Varjas, K., Meyers, J., Henrich, C., dan Brack, J. (2017). Coping with bullying: The moderating effects of self-reliance. Journal of School Violence, 18, 62-76. https://doi.org/10.1080/ 15388220.2017.1387131

Ramadhani, A., dan Retnowati, S. (2013). Depresi pada remaja korban bullying. Jurnal Psikologi UIN Sultan Syarif Kasim, 9, 73-79. https://doi.org/10.24014/JP.V9I2.165

Ratcliff, J. J., Lieberman, L., Miller, A. K., dan Pace, B. (2017). Bullying as a source of posttraumatic growth in individuals with visual impairments. Journal of Developmental and Physical Disabilities, 29, 265-278. https://doi.org/10.1007/s10882-016-9523-z

Reynolds, C. R., dan Kamphaus, R. W. (2004). Behavior assessment system for children (2nd ed.). AGS Publishing Roland.

Risner, D. (2014). Bullying victimisation and social support of adolescent male dance students: An analysis of findings. Research in Dance Education, 15, 179-201. https://doi.org/10.1080/146478 93.2014.891847

Santrock, J. W. (2011). Life-span development (13th ed.). New York: McGraw-Hill.

Sari, A. P., dan Jatiningsih, O. (2015). Konsep diri pelaku dan korban bullying pada siswa SMP Negeri 1 Mojokerto. Kajian Moral Dan Kewarganegaraan, 3, 1194-1209. 
Shafiira, F. N., Widiastuti, R., dan Pratama, J. (2020). Hubungan antara konformitas teman sebaya dengan perilaku perundungan (bullyinh). ALIBKIN (Jurnal Bimbingan Konseling), 8.

Slonje, R., Smith, P. K., dan Frisén, A. (2016). Perceived reasons for the negative impact of cyberbullying and traditional bullying. European Journal of Developmental Psychology, 14, 295-310. https://doi.org/10.1080/17405629.2016.1200461

Smokowski, P. R., Evans, C. B. R., dan Cotter, K. L. (2014). The differential impacts of episodic, chronic, and cumulative physical bullying and cyberbullying: the effects of victimization on the school experiences, social support, and mental health of rural adolescents. Violence and Victims, 29, 1029-1046. https://doi.org/10.1891/0886-6708.VV-D-13-00076

Takizawa, R., Maughan, B., dan Arseneault, L. (2014). Adult health outcomes of childhood bullying victimization: Evidence from a five-decade longitudinal British birth cohort. American Journal of Psychiatry, 171, 777-784. https://doi.org/10.1176/appi.ajp.2014.13101401

Taku, K., Kilmer, R. P., Cann, A., Tedeschi, R. G., dan Calhoun, L. G. (2012). Exploring posttraumatic growth in Japanese youth. Psychological Trauma: Theory, Research, Practice, and Policy, 4, 411-419. https://doi.org/10.1037/a0024363

Tedeschi, R., dan Calhoun, L. G. (1999). Facilitating posttraumatic growth: A clinician's guide. New Jersey: Lawrence Erlbaum Associates, Inc.

Tedeschi, R. G., dan Calhoun, L. G. (2004). Posttraumatic growth: Conceptual foundations and empirical evidence. Psychological Inquiry, 15, 1-18. https://doi.org/10.1207/s15327965pli1501_0 1

Tennen, H. (2013). Positive change following trauma: Controversies and new directions. The 29th annual meeting of international society of traumatic stress studies. Philadelphia.

Umamy, F., Hidayat, W., dan Sitorus, M. E. (2019). Studi fenomenologi: Dinamika kesehatan korban bullying remaja di SMPN 2 Kecamatan Datuk Bandar Timur kota Tanjungbalai. Jurnal Muara Sains, Teknologi, Kedokteran Dan Ilmu Kesehatan, 3, 245. https://doi.org/10.24912/jmstkik.v3i2. 5111

UNESCO. (2017). School violence and bullying: Global status report. Retrieved from https: //resourcecentre.savethechildren.net/library/school-violence-and-bullying-global-status-report

Utomo, M. I. T. (2016). Strategi coping korban bullying verbal pada siswa kelas XI di SMA Negeri 11 Yogyakarta. Jurnal Riset Mahasiswa Bimbingan Dan Konseling, 5.

Yayasan Semai Jiwa Amini. (2008). Bullying: Mengatasi kekerasan di sekolah dan lingkungan. PT. Grasindo.

Yin, X. Q., Wang, L. H., Zhang, G. D., Liang, X. B., Li, J., Zimmerman, M. A., dan Wang, J. L. (2017). The promotive effects of peer support and active coping on the relationship between bullying victimization and depression among chinese boarding students. Psychiatry Research, 256, 59-65. https://doi.org/10.1016/j.psychres.2017.06.037

Zakiyah, E. Z., Fedryansyah, M., dan Gutama, A. S. (2018). Dampak bullying pada tugas perkembangan remaja korban bullying. Focus : Jurnal Pekerjaan Sosial, 1, 265. https://doi.org/10.24198/foc us.v1i3.20502

Zelenski, J. M., Santoro, M. S., dan Whelan, D. C. (2012). Would introverts be better off if they acted more like extraverts? Exploring emotional and cognitive consequences of counterdispositional behavior. Emotion, 12, 290-303. https://doi.org/10.1037/a0025169 